\title{
Models of Work-Integrated Learning in Journalism Education
}

For submission to Journalism Studies

Faith Valencia-Forrester*

Griffith University

ORCiD 0000-0003-3871-5311

*Corresponding author: faith.valencia-forrester@griffith.edu.au

\begin{abstract}
Practice-based learning is widely accepted as a crucial aspect of educating and training future journalists around the world. Shrinking newsrooms and changing media landscapes shift responsibility onto journalism programs for delivering practical experiences. While internships are by far the predominant model, limited opportunities and concerns over equitable access to placements has prompted journalism educators to explore suitable alternatives. This article presents a typology of work-Integrated Learning (WIL) in journalism education, identifying the strengths and limitations of different models. Work-integrated learning is an umbrella term encompassing a wide range of forms of experiential education. Taking a critical approach, this article presents a typology of different models of WIL in journalism education from traditional models, such as internships, to emerging approaches including university-led WIL, pop-up newsrooms and Purpose WIL. In offering an overview of the various approaches to WIL in journalism education, this article aims to highlight the gaps in how journalism WIL has been implemented and suggests an agenda for enlivening and broadening WIL in journalism education. More equitable and accessible WIL closely linked to the needs of the industry ensures that future journalists have the graduate capabilities necessary for employment in a dynamic media landscape.
\end{abstract}

Keywords

Internships, journalism, work-integrated learning, inclusion, university-led WIL 


\section{Introduction}

The question of how best to train and prepare future journalists is intrinsically tied to the role of journalists in society. Are the journalists of the future mere content creators, reacting to the news of the day? Or are they citizen-activists, working critically in the public interest as the Fourth Estate? Cohen (2015) discusses the vexed nature of the debate on how best to educate and train journalists in the context of a vastly transformed media landscape. What has remained constant though, in an industry characterised by flux, is the importance of practical learning.

While practical learning may take any number of forms, this article focusses on Work-Integrated Learning (WIL) in journalism education. WIL in Australia is widely referred to as an 'umbrella' term for programs that integrate student academic and workplace knowledge (Patrick et al., 2009). WIL embodies the intentional integration of theory with practical knowledge and learning (Orrell, 2011), and Bowen (2018, p. 1148) describes WIL as the 'theory-to-practice approach of integrating disciplinary knowledge and skills with practical applications'. WIL is particularly critical in journalism education. Factors such as the rise of social media, declining advertising revenues for traditional media and the concentration of media ownership have resulted in a dramatically reconfigured media landscape, which, in turn, has seen heightened competition and reduced opportunities for graduate employment (Hirst, 2010, Wahl-Jorgensen and Hanitzsch, 2009). It is no longer enough for journalism graduates to be proficient in workplace skills and have a portfolio of published work, they also need to build their own personal brand in media markets (Cowgill, 2014). Further, consolidating newsrooms mean that the knowledge and skills base of journalists has expanded to include not only multimedia production, social media, photojournalism and desktop publishing, but also those of an entrepreneur (Mensing and Ryfe, 2013). As the key competencies required of journalists expand and as news industries across the western world experience a slow decline (Macnamara, 2016, Compton and Benedetti, 2010), practice-based journalism education must evolve beyond the traditional internship model in order to equip students with the skills they need to thrive in this challenging industry environment.

With newsrooms shrinking, increasing emphasis placed on practical experience within journalism programs, and issues with varying quality of internships, educators have had to be creative about how they incorporate the student-valued authentic experience within programs to produce 'workready' graduates. Journalism educators have had to develop a number of innovative models of WIL that draw from and, in some cases, challenge the dominant internships model. By creating this typology, this paper offers a conceptual analysis of the debates surrounding the various approaches to WIL in journalism education. This article begins by discussions some of the traditional approaches to WIL in journalism education, starting off with the internships model before discussing the hospital model, international WIL, and capstone courses. Having established some of the more traditional models of WIL, this article then turns to emerging alternative models of WIL including pop-up newsrooms, online simulations, Flipped WIL, Event WIL, and Purpose WIL. Finally, this article presents a summary of the models discussed in light of several key areas for consideration when implementing WIL in journalism education. Assessing these models of WIL takes into account what Billett (2011) terms the 'affordances' offered to participating students, the agency students are able to exercise, the accessibility of each model, and finally the implications for academic workloads. Each of these represent important considerations for implementing WIL experiences within journalism education. 


\section{Traditional WIL}

\section{Internships}

By far the most predominant model of WIL in tertiary journalism education is internships. As Skinner et al $(2001$, p. 35) have argued, the 'number of internship opportunities it affords' has even been a key measure for evaluating the success of a journalism school. Despite this, research on journalism internships has been limited (Forde and Meadows 2011). Drawing on data from a peer reflective session with final year journalism students at the completion of an internship, Forde and Meadows (2011) revealed great workplace variability in student experiences of internships. Relatedly, students reported gaining most from having a range of internship opportunities. What Forde and Meadows (2011, p. 3) highlight is that 'different kinds of learning occur in different settings". They also describe how the 'repertoire of experience' gained from the workplace 'leads to rich associations between ideas that are central to higher order conceptual knowledge required for effective performance in work tasks' (Billett, 2001a, p. 10). Notably, the peer reflection sessions following internships emerge as crucial to student learning as they voice both positive and negative experiences.

The beneficial but equally problematic nature of internships is foreshadowed in a description of the program at the University of Tasmania by Thomas and Goc (2004). Students, industry and academics report excellent outcomes but notably the course has a quota of 25 and is only offered to 'the best students' as 'the industry does not see itself as a training ground' but rather 'as a place for talented journalism students, almost ready for the workforce, to gain invaluable experience' (Thomas and Goc, 2004, p. 154). Equity concerns about internships are further elaborated upon by Mabweazara and Taylor (2012) through two case studies of student experiences. They report on two students Carla and Jodie enrolled at a university in the United Kingdom. Carla completed two work placements at high profile magazines where she enjoyed many positive WIL experiences. Her work was published and she extended her professional networks. In contrast, as the authors state Jodie 'was not so lucky' (Mabweazara and Taylor, 2012, p. 126). She was not successful in securing an internship with a nearby employer. While she was offered an internship in London she was unable to accept for economic reasons. With no other options Jodie undertakes a university-led library project which presents few opportunities for publication or interaction with professional peers. Jodie's inferior experience is crucial, given that, as Mabweazara and Taylor (2012, p. 127) contend, 'students are unlikely to be able to progress into the profession without a minimum amount of work experiences'.

Bromley et al. (2012, p. 102) have also examined internships as the 'most visible and traditional form of experiential learning in university journalism programs'. Using interviews and survey data they confirm the problem of variability in internship experiences. Interns identify their motivations for undertaking WIL as obtaining practical knowledge, making contacts, building a reputation and publishing work. A concerning finding was that there was little critique by students of industry practices. They report that 'without any critical comment' one student described the editor of the newspaper at which she interned as not being 'uptight about getting the quotes absolutely right' (Bromley et al., 2012, p. 106). Thus, while theory and practice should be linked in quality WIL this demonstrates that this is not always the case.

\section{The hospital model}

The hospital method has gained traction in journalism education literature in recent years. The model emanated from the United States, where it was first utilised in disciplines such as health and engineering. Newton (2013, n.p.) defines the hospital method as 'a model of learning-by-doing that 
includes college students, professors and professionals working together under one "digital roof" for the benefit of a community.' He explains that the US teaching hospital method in journalism education scaffolds experience throughout the degree program, and in some institutions, incorporates at least two semesters of 'experience' for credit. Accepted formats for the hospital method include: internships, innovation labs; field practicums, or students participating as staff on university-led publications (for example, the programs operating at Arizona State and the University of Maryland). In 2014, Arizona State University began operating Arizona's PBS (Public Broadcasting Service) "a member-supported community service of Arizona State University, based at the Walter Cronkite School of Journalism and Mass Communication" (Arizona State University, 2019). Klinger (2013), writing for The Poynter Institute, published a review of the hospital method at an Alabama University, referencing successful employment rates of over $90 \%$ of students from a journalism Masters program. A student argued that the hospital model ensured they had access to 'on-campus coursework with a full-time residency in a newsroom' (Klinger, 2013 n.p.).

The hospital teaching method has been slow to take hold, but it is gaining traction. Bowman and Lund (2007) detail the practical nature of their radio and video journalism units at an Australian university, but do not account for the multimedia and multi-platform nature of current newsrooms. Similarly, Davies et al. (2017, p. 221) describe a multi-university national reporting project covering the 2016 Australian federal election which they refer to as the 'teaching hospital' method and as a 'source of experimentation and debate in journalism education circles.' In a study spanning across six Nordic countries, Jaakkola (2018) describes what she terms 'pedagogical newsrooms'. These pedagogical newsrooms are led by journalism educators with a background in industry and are aimed at creating a 'critical surplus' reflecting the relationship between academia and industry, rather than necessarily replicating a professional newsroom.

The hospital model has been criticised by Mensing and Ryfe (2013, p. 2) who argue that the method does not produce journalists for a changed and changing media landscape instead reinforcing the conviction that content delivery is the primary purpose of journalism'. Rather than the 'hospital method', Mensing and Ryfe (2013) instead advocate for an 'entrepreneurial method'. They suggest journalism educators should be preparing students for changing careers and encouraging students to engage in experimentation. In addition, they argue that journalism education should incorporate teaching strategies for students to develop an understanding of audiences, to engage with social media, to focus on demand (audiences), be publication driven and to extend their networks through actual reporting. This is the epistemology informing some of the more recent and alternative WIL models in journalism which are explored below.

\section{International WIL}

There have been a number of extensive explorations of International WIL in journalism education, which involves students undertaking practice-based learning overseas, either through a 'field trip' supported by faculty or by undertaking an international placement. Duffield (2014) has written extensively on the former model and argues for the internationalisation of journalism curriculum based on his work over a number of years taking journalism students on overseas field trips. Duffield $(2008$, p. 102) argues that the trips 'replicate journalistic practice of overseas correspondents encountering "high risk and high returns": more difficulty, more headlines and colour'. Building on this work, Woolley $(2014,2015,2017)$ also argues for the educational benefits of taking students overseas and teaching them how to be foreign correspondents. He argues that, despite the difficulties associated with taking students into different cultures, students develop intercultural communication skills in the field. Both authors (Woolley, 2017, Duffield, 2014, Duffield, 2008) report positive employment outcomes for students who participated in these field reporting experiences. 
Another model of International WIL sees students travel independently and contribute content to a purpose-built website, rather than undertake a field reporting trip. This approach is said to prepare students who might be undertaking internships overseas rather than at local media outlets (Wake et al., 2017). This approach has clear parallels with the internships model, in more ways than one. International WIL presents a number of equity concerns, the least of which is the affordability of such experiences for all students. There may also be restrictions places on such experiences. Duffield writes that the International WIL programs were only available to small groups of 'advanced level students' (Duffield, 2008, p. 206). In addition to these issues, Wake, Sison and Muir (2017) also detail the extensive workload of staffing these experiences, with students often needing a high level of pastoral care from supervising academics in order to complete international internships successfully.

Garrison (2010) brings international WIL and blogging in a description of journalism students from the University of Miami travelling overseas to China and Thailand between 2006 and 2010. He also links blogging and an alternative model of WIL, Event WIL, in discussing another group of students travelling to Idaho to produce content for the Special Olympic World Winter Games. Garrison (2010) argues that developments in technology allow journalism education to happen on the road and suggests that journalism students incorporate blogging as reporting into their travel. Stoker $(2015, \mathrm{p}$. 179) also champions blogging as adding 'another dimension to WIL' as it can be used to 'develop transferable skills, abilities and behaviours expected of graduates' in journalism. While also an advocate of blogging Forbes (2010) sees its usefulness in terms of WIL as facilitating the critically important task of reflection.

\section{Capstone courses}

Another way in which WIL in journalism has been discussed in the literature has been through the lens of the 'capstone course'. Tanner et al (2012, p. 220) completed an analysis of journalism programs in 113 schools and 20 interviews with instructors of capstone broadcast units in the United States, and suggest capstone courses are necessary for students to 'integrate and apply the knowledge they have learned', and 'may include hands-on experience'. In Australia, Cullen has written extensively on capstone courses that demonstrate graduate capabilities in journalism education. He also argues that there need to be more consistent standards across the various Australian journalism programs in terms of capstone courses and the employment capabilities they aim to demonstrate. In a departure from the dominant model, he argues that industry placements have limitations in terms of a capstone course. In addition to dwindling opportunities for placements, Cullen (2015) interviewed 50 news editors and identified that there is the perception that some students are not as proficient in terms of skills as expected and therefore are not included in newsroom operations. Cullen (2015) reports that these students are often assigned menial tasks. Other barriers for students obtaining practical experience in industry placements include the need for students to negotiate with unit coordinators for placement opportunities. Without stipulating what a capstone journalism unit would look like, Cullen (2015) proposes developing a series of criteria, strategies and standards to guide journalism educators in the design of journalism capstone units, and suggests these are established via wide consultation, panel discussions, and a discussion paper be distributed to inform the development of a capstone journalism unit

In a more recent work, Cullen (2017) found that while capstone style courses have been included in other disciplines for many years, they have only really gained prominence in journalism programs in the past decade. Following a series of face-to-face interviews with journalism educators from 18 universities, he identifies the three main types of capstone courses as being newsroom simulation, projects, and internships. Interviewees report that the units aim to be student-centred and are focused on students demonstrating core journalism skills and producing publishable outcomes. 
Cullen (2017) recommends that capstone courses in journalism attend to skills development, integration and closure, diversity, engagement, assessment and evaluation.

\section{Alternative WIL models}

In more recent years, other WIL models have emerged in journalism education alongside the more traditional approaches. Fulton et al (2017) detail how, in response to the Australian National WIL Strategy released in 2015, journalism and communication educators at the University of Newcastle undertook a series of innovative WIL experiences for students in the journalism program. They highlighted that, regardless of the format, WIL experiences must be authentic and embedded; as they put it: “'Tacking on" a work placement to a degree program is not WIL' (Fulton et al., 2017, p. 11). With this in mind, the following section explores a number of emerging alternative models of WIL. Though some significantly differ from the more traditional, internship-focussed approaches, they represent new ways of embedding authentic, practice-based learning into a journalism education curriculum.

\section{Pop-up newsrooms}

The concept of a pop-up newsroom for student journalists has gained increasing popularity over the past few years. Wall (2015) describes a university-run pop-up newsroom as a temporary, citizen journalism-style, mobile news operation staffed by student journalists. In this instance, the pop-up was a collaborative multinational project and tied to raising students' critical capacities in relation to the reporting of poverty. Pop-up news rooms have also been adopted by large media organisations such as Google and Facebook, which have partnered with universities and media outlets to report on projects and events.

Pop-up newsrooms have been employed on multiple occasions to cover major national events such as elections. Steel et al (2007) document another pop-up newsroom established for three days at the University of Sheffield to cover a general election in the United Kingdom. Further, a collective of Australian journalism academics established a pop-up newsroom to cover first a state election, and then a national election. The project, titled UnipollWatch, involved four universities collaborating and publishing student reporting on the 2014 Victorian state elections (Dodd et al., 2015). For the 2016 project, Davies et al. (2017) highlighted the potential for the collaborative nature of the project to assist in "forging a better future for journalism education in Australia." Content from students was published on a purpose-built website to avoid having the project branded by any one university. How the universities engaged with the project was left for each of the universities to determine and student participation ranged from less than ten to over 100 students. Some of the universities incorporated the project into existing units while others created stand-alone options for students.

Pop-up newsrooms link closely to Event WIL, another alternative model of WIL. Indeed, Steel et al (2007: 333) conclude their research by suggesting that there are 'benefits of focusing on specific important events' around which 'students become journalists for a short time' and suggest that further empirical work on the model is needed. Further examples of this connection include a case study by Furlan (2007) of students covering the South Australian World Police and Fire Games and another by St Clair (2015) of student journalists involved in the Bluesfest music festival at Byron Bay in Australia. In all instances, students reported developing professionally and personally as a result of their involvement in the programs. 


\section{Online simulations}

Another alternative model of WIL in journalism education is online simulations. Simulations serve to test how well students are able to implement concepts from their training (Veil, 2010). Online simulations allow for greater accessibility, as location and physical access are not barriers to participation. Online simulations also offer students exposure to the broader context of their reporting. Tanner (2005) writes of his online simulation that brought together journalism students in Australia and Papua New Guinea to conduct an investigative reporting project into a fictional wildlife smuggling syndicate. Other approaches to online simulations can be seen in the work of Holt et al. (2013), who conducted an e-simulation of a radio workplace, and Eberholst et al. (2016) who developed an online newsroom for Danish journalism students. In both instances, the authors argue that they simulated the types of real challenges experienced daily in newsrooms including interpersonal, ethical and legal issues. Notably, Seagrave and Holt (2013) argue that technology enhanced simulation models of WIL to overcome the problem of large student numbers, limited staff numbers, and limited student placements. In contrast, Tanner $(2005$, p. 93$)$ suggests that his experience with online simulation aimed to emphasize to students the importance of 'the traditional boot leather approach to reporting' rather than encouraging 'desk-bound journalism'. Online simulations represent a relatively unexplored area of WIL in terms of journalism education. While there have been notable experiments, such as those discussed here, there is much work to be done in this area to further explore the potential of online simulations as WIL in journalism education.

\section{Event WIL}

Event WIL represents an emerging model of WIL that draws from both traditional models, such as capstone course and internships, and alternative models including pop-up newsrooms. Event WIL takes up Bjorck and Johnansson's (2018, p. 10) problematizing of the dichotomies which frame so many discourses about WIL such as 'theory/practice' and 'university/industry' and instead creates a 'third place for WIL' that is truly integrative. While integration is viewed as fundamental to WIL what it means and how it can be achieved are still not yet well articulated in the literature (Zegwaard and Coll, 2011). A form of university-led WIL, Event WIL inverts the internship model by bringing industry into the classroom. This requires establishing a shared professional space where industry, students, and staff work alongside one another. Students are part of a newsroom providing real-time coverage working for an alongside professional media content producers and journalists. Event WIL was developed through several case studies emerging from Griffith University in Australia. Students worked closely with industry to cover a series of major events from the G20 Leaders' Summit to the Commonwealth Games (author withheld). These iterations of Event WIL had significant outcomes for students, the least of which was the widespread distribution and publication of their work in both student and national media outlets. Not only did this add weight to the students' portfolios, but this close engagement with industry was directly responsible for a number of subsequent industry placements and even paid employment. Notably, industry partners also reported positive experiences with Event WIL. Partners appreciated the increased coverage of the event that students were able to provide, as well as the strengthened partnerships with the university.

\section{Purpose WIL}

Another form of contemporary WIL in journalism is what could be described as Purpose WIL. Purpose WIL draws on a framework of advocacy journalism to introduce students to reporting on a specific social issue. Fisher (2016, p. 172) states that there is no 'fixed definition' of advocacy journalism, but instead an 'advocacy continuum' in that every piece of journalism contains elements of advocacy, whether intentional or not, and therefore can be placed on a continuum ranging from 'overt' to 'subtle'. The form of advocacy journalism utilised in Purpose WIL projects aligns with the 
form of advocacy journalism which arose in the 1960s and was associated with civil, environmental, gay and lesbian and women's rights (Waisbord, 2009, p. 372). Though more participatory forms of journalism, such as civic journalism (Tully et al., 2017) or public journalism (Simpson, 2014), may seem more appropriate for working towards social change outcomes, in terms of education, these complex approaches require more time, stronger relationships with audiences, and more nuanced reporting than can be expected of inexperienced student journalists (Gumucio-Dagron and Rodríguez, 2006).

As well as advocacy journalism, Purpose WIL draws on the principles of strengths-based reporting. Such an approach aims to critique and redress media representations of vulnerable people. Strengths-based reporting is particularly important given the dominant 'deficit-based' media discourses surrounding reporting on Indigenous people (Coleby and Giles, 2013). As such, a number of the case studies of Purpose WIL in journalism education in Australia have focused on Indigenous issues. Johnston and Bishop (2012) label their case study an example of 'unconventional WIL'. This descriptor highlights the project's emphasis on cultural inclusion in production and broadcast environments rather than on developing knowledge and skills of journalism students. Johnston and Bishop (2012) explain that the project involved undergraduate journalism students producing an Indigenous television program for national broadcast on campus using university facilities. In another example of WIL journalism focused on Indigenous issues, Stewart et al. (2010) describe a project in which students first undertook an intensive unit on respectfully reporting on Indigenous people. Following this, students wrote stories about issues impacting upon the lives of Indigenous people with their work appearing in Indigenous media outlets in Australia and Canada. A similar critical and reflexive lens was brought to a WIL experience designed by Mason et al. (2016) which involved students working alongside Indigenous community partners, including media representatives, to address problems in the mainstream media's reporting of Indigenous issues.

There have been other cases of employing Purpose WIL to address social issues in Australia. Several iterations of Purpose WIL have taken place at Griffith University, covering topics such as domestic violence, reporting on disability, mental health, and refugees. The first project, titled Project Safe Space, was conceived in response to the Australian media's problematic reporting on domestic violence. The aim of the project was to educate future journalists about domestic violence, and by adopting strengths-based reporting, highlight the misconceptions and misunderstandings surrounding the actions and behaviours of those affected by domestic violence (Valencia-Forrester and Backhaus, 2018). Students worked with industry and community partners, including support services and Members of Parliament, to develop a body of work of 58 multimedia stories housed on a custom-built website that included support resources.

\section{Flipped WIL}

Flipped WIL model is an adaptation of what the literature describes as the 'teaching hospital' method (Newton 2012, 2013) while engaging with criticisms challenging the notion that journalism education is simply a method of 'supply' (Young and Giltrow 2015, Anderson et al 2011; Mensing and Ryfe 2013). The Flipped WIL model is a mixture of core and elective practice-based units, scaffolded through the final half of the program culminating in a capstone unit. Each unit is designed to afford all students a range of authentic quality WIL experiences within a contemporary hybridised multimedia newsroom. Students engage in authentic journalism practice producing timely content broadcast live on radio, television, or published on an industry standard online news platform. Woven into their 'practice of journalism is a critical engagement with theoretical concepts. Here, journalism students are also able to explore other facets of journalism including 
'entrepreneurship, intellectual property, managing social networks, curating content, or digital security' (Berger and Foote 2017, p. 249). Most importantly, the Flipped WIL model is designed and developed around the notion of inclusion and it's main focus is ensuring all students have equitable access to a quality WIL experience. Each of the units involve student learning occurring through students 'working' as journalists. At the core of the model is a student centred approach to designing WIL experiences, while at the same time strengthening collaboration between 'the WIL tripartite partnership of employer, academic staff, and student' (Martin et al 2012, p 24).

\section{Assessing models of WIL}

\begin{tabular}{|c|c|c|c|c|c|}
\hline & Management & $\begin{array}{l}\text { Industry } \\
\text { exposure }\end{array}$ & $\begin{array}{l}\text { Student } \\
\text { agency }\end{array}$ & Accessibility & $\begin{array}{l}\text { Staff } \\
\text { workload }\end{array}$ \\
\hline \multicolumn{6}{|l|}{ Traditional WIL } \\
\hline Internships & Industry & High & Low & Low & Low \\
\hline Hospital model & $\begin{array}{l}\text { University- } \\
\text { led }\end{array}$ & Moderate & Moderate & Moderate & Moderate \\
\hline International WIL & $\begin{array}{l}\text { University- } \\
\text { led }\end{array}$ & Low & Moderate & Low & High \\
\hline Capstone units & $\begin{array}{l}\text { University- } \\
\text { led }\end{array}$ & Moderate & Moderate & Moderate & Moderate \\
\hline \multicolumn{6}{|l|}{ Alternative WIL } \\
\hline $\begin{array}{l}\text { Pop-up } \\
\text { newsrooms }\end{array}$ & $\begin{array}{l}\text { University- } \\
\text { led }\end{array}$ & High & High & Moderate & High \\
\hline Online simulations & $\begin{array}{l}\text { University- } \\
\text { led }\end{array}$ & Low & Moderate & High & High \\
\hline Event WIL & $\begin{array}{l}\text { University- } \\
\text { led }\end{array}$ & High & High & Moderate & High \\
\hline Purpose WIL & $\begin{array}{l}\text { University- } \\
\text { led }\end{array}$ & High & High & High & High \\
\hline Flipped WIL & $\begin{array}{l}\text { University- } \\
\text { led }\end{array}$ & Moderate & High & High & High \\
\hline
\end{tabular}

TABLE 1: SUMMARY OF WIL MODELS

There is clearly a wide range of approaches to WIL in journalism education, each with their advantages and disadvantages. Though it is clear from the literature discussed throughout this article that students are able to benefit in different ways from any number of WIL models, there are other considerations aside from student learning. Table 1 represents a summary of the models discussed throughout this article and several key considerations for assessing these models. In assessing the potential of different WIL models in journalism, this paper draws on the work of Billett who has made a significant contribution to debates on quality WIL. A key tenet of his recent work is that, given WIL is now widely taken up in higher education, it is 'important to find ways of optimising the learning potential' of the experiences (Billett et al., 2018, p. 1281). In an earlier review of 20 WIL projects conducted by six participating universities investigating the integrating experience of higher education students across practice and university settings, Billett (2011) evaluates projects in terms of their 'educational worth' and identifying the kinds of knowledge that students needed to prepare them for the workplace. Key findings emerging from this analysis of these projects include the need for preparing and extending students for and beyond the WIL experience. Billett (2007) also highlights the role the agency of learners and the role the individual plays in their. In a later work, he 
relates the success of individual placement to the level of 'affordances' provided by the employer and engagement the experienced by the student in the practice placement (Billett, 2011, p. 10). Billett (2001b, p. 209) describes affordances as 'the workplace's readiness to afford opportunities for individuals to engage in work activities' with both direct and indirect support being key factors contributing to the quality of learning.

The management of WIL experiences is also an important factor to consider. While exposure to industry is of vital importance, both in terms of student learning and networking, university-led models are generally more inclusive: offering experiences to all students, not just the best and brightest. When WIL is university-led, all students can access a quality WIL experience. They can do so in a supportive environment where additional social and welfare services are readily available and where they have access to support staff who have an understanding of their needs, strengths and weaknesses. This is crucial given that support, both directly and indirectly is a 'key determinant' of quality learning in WIL (Billett, 2001a, p. 1). Within a university-led WIL model, students have a safety net to develop skills and make mistakes in a professional environment and learn from them. Students who may not have been offered a premium industry placement are still afforded the same experience and opportunities to produce published work for graduation.

A further area for consideration is how WIL acknowledges and enhances student agency. Billett $(2011,2002)$ has been instrumental in drawing attention to the importance of student agency in the WIL experience. The importance of 'affordances' in workplaces for quality WIL but suggests that this is 'one side of the reciprocal processes of participation and learning' with the other being agency (Billett, 2002, p. 29). While inclusive WIL requires agentic subjects, WIL practitioners can foster agency by using student-centred pedagogies, allowing for diversity of learning styles and building students' confidence through scaffolding skill development.

Finally, resourcing is another challenge for WIL. While recognising that the costs of WIL programs will vary, McLennan and Keating $(2008$, p. 11) assert that WIL is 'resource intensive' in terms of 'the transaction costs of maintaining partnerships with many employers, sourcing WIL opportunities, developing and evaluating curriculum for WIL and supporting a body of students who are geographically dispersed.' As Clark et al. (2016) report, to date most of the evidence about WIL workloads has been anecdotal. However, emerging research suggests that there is considerable cause for concern. Jovanovic, Fane and Andrew (2018) report on the high workloads of WIL educators in early childhood programs noting the 'mismatch' between them and 'existing expectations about standard academic workloads'. Further, Bates (2011, p. 120) draws on survey data from academics involved in WIL to demonstrate that the 'highly contextualised and individual' nature of WIL adds significantly to the workloads of university educators, but that this is seldom recognised or rewarded by management. Unsurprisingly, involvement in WIL is viewed by many academics as an impediment to promotion and to research (Von Treuer and McMurray, 2012). The gendered aspect of WIL labour adds a further layer of complexity, with the majority of WIL work undertaken by women, and by women who are at lower levels in the academic hierarchy (Bates, 2011). This represents a key area for future research and an important consideration when implementing any model of WIL in journalism education.

\section{Conclusion}

There are clear challenges when it comes to educating and training the journalists of the future. The changing nature of the industry and its subsequent requirements on its workers mean that practice- 
based, experiential education is essential for tertiary journalism programs to produce work-ready graduates. This article has discussed and developed a typology of several different approaches to work-integrated learning, or WIL. Employed as an umbrella term, WIL refers to programs that integrate academic and workplace knowledge and may include a vast range of approaches and models (Patrick et al., 2009). WIL has been widely used in journalism education, though mostly in the form of the traditional internship model. Given the huge changes taking place in the media industry, as well as questions around the equitability of internships, journalism educators are increasingly incorporating creative approaches to facilitating practice-based learning. This article highlighted four traditional models of WIL - internships, the hospital model, international WIL, and capstone courses - and five alternative models of WIL - pop-up newsrooms, online simulations, Event WIL, Purpose WIL, and Flipped WIL. Each of these models have their own unique set of advantages and disadvantages. While there is a belief in 'the general "good" of WIL' (Smith and Worsfold, 2015, p. 1079), challenges remain, particularly around equitable access to experiences and academic workloads. This article offers a typology of approaches to WIL in journalism education, which represents a valuable first step towards embedding inclusive, practice-based learning experiences within tertiary journalism education. More equitable and accessible WIL that is closely linked to the needs of the industry ensures that future journalists have the graduate capabilities necessary for employment in a dynamic media landscape. 


\section{References}

ARIZONA STATE UNIVERSITY. 2019. Arizona PBS [Online]. Phoenix, AZ. Available: https://azpbs.org/about/ [Accessed].

BATES, M. 2011. Work-integrated learning workloads: The realities and responsibilities. Asia-Pacific journal of cooperative education, 12, 111-124.

BILLETT, S. 2001a. Knowing in practice: Re-conceptualising vocational expertise. Learning and instruction, 11, 431-452.

BILLETT, S. 2001b. Learning through work: workplace affordances and individual engagement. Journal of workplace learning, 13, 209-214.

BILLETT, S. 2002. Toward a workplace pedagogy: Guidance, participation, and engagement. Adult education quarterly, 53, 27-43.

BILLETT, S. 2007. Exercising self through working life: Learning, work and identity. Identities at work. Springer.

BILLETT, S. 2011. Curriculum and pedagogic bases for effectively integrating practice-based experiences, Australian Learning and Teaching Council Sydney.

BILLETT, S., CAIN, M. \& LE, A. H. 2018. Augmenting higher education students' work experiences: Preferred purposes and processes. Studies in Higher Education, 43, 1279-1294.

BJÖRCK, V. \& JOHANSSON, K. 2018. Problematising the theory-practice terminology: a discourse analysis of students' statements on Work-integrated Learning. Journal of Further and Higher Education, 1-13.

BOWEN, T. 2018. Becoming professional: examining how WIL students learn to construct and perform their professional identities. Studies in Higher Education, 43, 1148-1159.

BOWMAN, L. F. \& LUND, A. 2007. Pathways to the profession: a study in integrating journalism degree programs with the world of work.

BROMLEY, M., HARRISON, J. \& FRANGI, A. 2012. Student perceptions of journalism as an occupation: The view from the front of the class. Australian Journalism Review, 34, 99-114.

CLARK, L., ROWE, A., CANTORI, A., BILGIN, A. \& MUKURIA, V. 2016. The power dynamics and politics of survey design: measuring workload associated with teaching, administering and supporting work-integrated learning courses. Studies in Higher Education, 41, 1055-1073.

COHEN, N. S. 2015. Entrepreneurial journalism and the precarious state of media work. South Atlantic Quarterly, 114, 513-533.

COLEBY, J. \& GILES, A. R. 2013. Discourses at work in media reports on Right To Play's "Promoting Life-Skills in Aboriginal Youth" program. Journal of Sport for Development, 1, 1-14.

COMPTON, J. R. \& BENEDETTI, P. 2010. Labour, new media and the institutional restructuring of journalism. Journalism studies, 11, 487-499.

COWGILL, C. L. 2014. 'Last Best News' Shows How Personal Brand Journalism Works in Local Markets. Mediashift [Online]. Available: http://mediashift.org/2014/07/last-best-newsshows-how-personal-brand-journalism-works-in-local-markets/.

CULLEN, T. 2017. Capstone units and the transition from university to professional life. Australian Journalism Review, 39, 89.

DAVIES, K., DODD, A., KREMMER, C. \& HEEKEREN, M. V. 2017. The pedagogy of the UniPollWatch pop-up journalism project. Asia Pacific Media Educator, 27, 219-232.

DODD, A., BULLER, B., CASTILLO, A., CLARKE, P., MARTIN, H., SCHWARTZ, L., SIMONS, M. \& ZION, L. 2015. UniPollWatch: a model for cross-campus political journalism education. Asia Pacific Media Educator, 25, 222-237.

DUFFIELD, L. 2014. Student reporting abroad: A journalism project built on internationalisation. Pacific Journalism Review, 20, 205. 
DUFFIELD, L. R. 2008. Student reporting abroad: An international programme called journalism reporting field trips. Pacific Journalism Review, 14, 102-122.

EBERHOLST, M. K., HARTLEY, J. M. \& OLSEN, M. B. 2016. Between ideals and practice: Journalism students facing ethical dilemmas in online newsroom teaching-Lessons from Denmark. Journalism \& mass communication educator, 71, 189-202.

FISHER, C. 2016. The advocacy continuum: Towards a theory of advocacy in journalism. Journalism, $17,711-726$.

FORBES, A. Reflecting, blogging and learning in journalism: Are journalists born or made. Work Integrated Learning-Responding to Challenges: Proceedings of the 2010 ACEN National Conference, 2010. Australian Collaborative Education Network, 156-164.

FORDE, S. \& MEADOWS, M. 2011. Industry placements in journalism education: Exploring enhanced learning and professional growth for interns. JRE Journal, 1.

FULTON, J., SCOTT, P., JAMES, M. \& SANDNER, J. A WIL and a way: Integrating authentic learning experiences to develop work-ready communication students. Refereed proceedings of the Australian and New Zealand Communication Association Conference, 2017.

FURLAN, P. 2007. Journalism Education and experiential learning. Australian Journalism Review, 29, 123.

GARRISON, B. 2010. Travel as a teaching approach for new media skills and writing courses. Asia Pacific Media Educator, 123.

GUMUCIO-DAGRON, A. \& RODRÍGUEZ, C. 2006. Time to call things by their name. Media Development, 53, 9.

HIRST, M. 2010. Journalism education "Down Under" A tale of two paradigms. Journalism Studies, 11, 83-98.

HOLT, D., SEGRAVE, S. \& CYBULSKI, J. L. 2013. E-Simulations for educating the professions in blended learning environments. IT Policy and Ethics: Concepts, Methodologies, Tools, and Applications. IGI Global.

JAAKKOLA, M. 2018. S ( $\mathrm{t}$ ) imulating Journalism in the Classroom: A Structured Comparison of the Design of Pedagogical Newsrooms in Nordic Academic Journalism Training. Journalism \& Mass Communication Educator, 73, 182-199.

JOHNSTON, M. \& BISHOP, R. 2012. Noongar Dandjoo: A work integrated learning case study. Asia Pacific Media Educator, 22, 165-177.

JOVANOVIC, J., FANE, J. \& ANDREW, Y. 2018. Giving institutional voice to work-integrated learning in academic workloads.

KLINGER, L. 2013. Journalism program takes lessons from teaching hospitals. Poynter [Online]. Available: https://www.poynter.org/reporting-editing/2013/journalism-program-takeslessons-from-teaching-hospitals/.

MABWEAZARA, H. M. \& TAYLOR, A. 2012. Exploring effective pedagogies for delivering journalism work-based learning in UK higher education. Journal of Media Practice, 13, 125-142.

MACNAMARA, J. 2016. The continuing convergence of journalism and PR: New insights for ethical practice from a three-country study of senior practitioners. Journalism \& Mass Communication Quarterly, 93, 118-141.

MASON, B., THOMSON, C., BENNETT, D. \& JOHNSTON, M. 2016. Putting the 'love back in'to journalism: Transforming habitus in Aboriginal affairs student reporting. Journal of Alternative and Community Media, 1, 56-69.

MCLENNAN, B. \& KEATING, S. Work-integrated learning (WIL) in Australian universities: The challenges of mainstreaming WIL. ALTC NAGCAS National Symposium, 2008. Citeseer, 2-14.

MENSING, D. \& RYFE, D. Blueprint for change: From the teaching hospital to the entrepreneurial model of journalism education. ISOJ The Official Research Journal of the International Symposium on Online Journalism, 2013. 26-44.

NEWTON, E. 2013. Searchlights and sunglasses: Field notes from the digital age of journalism. . Miami, FL: John S and James L Knight Foundation. 
ORRELL, J. 2011. Good practice report: Work-integrated learning. ALTC: Strawberry Hills.

PATRICK, C.-J., PEACH, D., POCKNEE, C., WEBB, F., FLETCHER, M. \& PRETTO, G. 2009. The WIL (Work Integrated Learning) report: A national scoping study, Queensland University of Technology.

SIMPSON, E. 2014. News, Public Affairs, and the Public Sphere in a Digital Nation: Rise of the Audience, Lexington Books.

SKINNER, D., GASHER, M. J. \& COMPTON, J. 2001. Putting theory to practice: A critical approach to journalism studies. Journalism, 2, 341-360.

SMITH, C. \& WORSFOLD, K. 2015. Unpacking the learning-work nexus:'priming'as lever for highquality learning outcomes in work-integrated learning curricula. Studies in Higher Education, 40, 22-42.

ST CLAIR, J. 2015. Doing it for real: Designing experiential journalism curricula that prepare students for the new and uncertain world of journalism work. Coolabah, 16, 122-142.

STEEL, J., CARMICHAEL, B., HOLMES, D., KINSE, M. \& SANDERS, K. 2007. Experiential learning and journalism education: Lessons learned in the practice of teaching journalism. Education+ Training, 49, 325-334.

STEWART, H., MEADOWS, M., BOWMAN, L., VAN VUUREN, K. \& MULLIGAN, P. 2010. Indigenous voice: A work-integrated learning case study in journalism education. Australian Journalism Review, 32, 59.

STOKER, R. 2015. An investigation into blogging as an opportunity for work-integrated learning for journalism students. Higher Education, Skills and Work-based Learning, 5, 168-180.

TANNER, S. 2005. Investigating the hypothetical: Building journalism skills via online challenges. Asia Pacific Media Educator, 1, 89-102.

TANNER, S., GREEN, K. \& BURNS, S. 2012. Experiential learning and journalism education: Special Olympics-a case study. Australian Journalism Review, 34, 115.

THOMAS, R. \& GOC, N. Cooperative education in journalism studies. 2004. WACE.

TULLY, M., HARMSEN, S., SINGER, J. B. \& EKDALE, B. 2017. Case study shows disconnect on civic journalism's role. Newspaper Research Journal, 38, 484-496.

VALENCIA-FORRESTER, F. \& BACKHAUS, B. 2018. Project Safe Space: wise practice in journalism education for advocacy and social change. Australian Journalism Review, 40, 93.

VEIL, S. R. 2010. Using crisis simulations in public relations education. Communication Teacher, 24, 58-62.

VON TREUER, K. \& MCMURRAY, A. J. 2012. The role of organisational climate factors in facilitating workplace innovation. International Journal of Entrepreneurship and innovation management, 15, 292-309.

WAHL-JORGENSEN, K. \& HANITZSCH, T. 2009. The handbook of journalism studies, Routledge.

WAISBORD, S. 2009. Advocacy journalism in a global context. The handbook of journalism studies, 371-385.

WAKE, A., SISON, M. D. \& MUIR, R. 2017. Supporting International Student Mobility Through Resourced International Internships. Asia Pacific Media Educator, 27, 249-263.

WALL, M. 2015. Change the space, change the practice? Re-imagining journalism education with the Pop-Up Newsroom. Journalism Practice, 9, 123-137.

WOOLLEY, B. 2014. WIL-power: Developing journalism students' intercultural communications and international reporting skills on field trips to Vietnam. Asia Pacific Media Educator, 24, 157173.

WOOLLEY, B. 2015. Developing skills in intercultural communication and international reporting through work integrated learning courses. Australian Journalism Review, 37, 187.

WOOLLEY, B. 2017. Teaching Undergraduate Journalism Students Foreign Correspondence: Can It Be Done? Asia Pacific Media Educator, 27, 85-102.

ZEGWAARD, K. E. \& COLL, R. K. 2011. Exploring some current issues for cooperative education. Journal of Cooperative Education and Internships 45, 8-15. 